\title{
A Novel Photoreaction of (2-Hydroxyethoxyphenyl)pentamethyldisilane
}

\author{
Seung Ki Park' and Won Je Seong \\ Department of Chemistry, College of Natural Sciences, The Universin of Sinton. P. O. Box 77. Stm on $445-743$, Korea \\ E-mail: skparkastinon.ackr \\ Received March 11, 2009, Accepted.April 29, 2009
}

\begin{abstract}
Photoly sis of (2-hydroxy'ethoxy'pheny l)pentamethyldisilane 2 in benzene provides a novel intramolecular cyclization photoproduct 9 which was probably fonmed from the intramolecular reaction to form a seven-membered ring in silatriene intermediate 7 and then the photochemical disrotatory ring closure of 1,3-butadiene moiety to cyclobutene. Irradiation of $\mathbf{2}$ in methanol afforded photoproducts $\mathbf{5}$ and $\mathbf{6}$ which were formed by the nucleophilic attack of methanol to $\beta$ or $\alpha$ silicon atom in pentamethyldisilanyl group of the photoexcited state of 2 . Compounds 10 and 11 were also formed by the same way as in the formation of the photoproducts 5 and 6 in the photoly sis of (2-ally loxyethoxy phenyl)pentamethyldisilane 3 in methanol solvent. Photoreaction of (2-acetoxyethoxyphenyl) pentamethyldisilane 4 in methanol gave a photoproduct 12 which was formed via the elimination of dimethylsilylene species in the photoexcited state of 4 .
\end{abstract}

Key Words: (2-Hydroxyethoxyphenyl)pentamethyldisilane. (2-Allyloxyethoxyphenyl)pentamethyldisilane. (2-Acetoxyethoxyphenyl)pentamethyldisilane. Silatriene

\section{Introduction}

Since the first report on the photolysis of phenylpentamethyldisilane and ( $p$-tolyl)pentamethyldisilane by Islikawa et al. ${ }^{j}$ in 1975 , photoreactions of aryldisilanes have been extensively investigated ${ }^{2-\hat{i}}$ However. relatively little is known about the photoreactions of ortho-substituted phenylpentamethyldisilanes.

Very recently. we have found that the photolysis of orthosubstituted phenylpentamethyldisilanes ${ }^{1-23}$ afforded novel intramolecular photoproducts via silatriene intermediates. In connection with our ongoing studies for the utility of silacyclopropenes. I-silaallenes. and silatrienes as reaction intermediates in organic synthesis of silicon-containing heterocyclic compounds ${ }^{2+}$ we were now interested in the synthesis of silicon-containing large ring compounds through the photolysis of ortho-substituted aryldisilanes. And. we have investigated the photoreactions of (2-hydroxyethoxy phenyl)pentamethyldisilane 2 . since novel photoproducts from the intramolecular reaction of ortho-substituted group with the silatriene intermediate. which is formed from the radical scission of a silicon-silicon bond followed by migration of the resulting trimethylsilyl radical to the $\mathrm{C}_{6}$ position of the benzene ring. are expected and we would like to report the detailed photochemical study of (2-hy'droxyethoxy'phenyl)pentamethyldisilane 2 and it's derivatives 3 or 4 .

\section{Experimental}

General methods. All reactions were carried out under an atmosphere of dry nitrogen. ${ }^{1} \mathrm{H}$ and ${ }^{13} \mathrm{C}$ NMR spectra were recorded on Bnuker AM-300 and Bnuker AC-200 spectrometers with chemical shifts being referenced against TMS as an internal standard or the signal of the solvent $\mathrm{CDCl}_{3}$. UV absorption spectra were recorded on a Hewlett-Packard 8453 spectrophotometer. Mass spectra were determined at $70 \mathrm{eV}$ with a Hew lett-Packard 5985A GC-MS by the electron impact (EI) method. FT-IR spectra were recorded on a Bomen MB100 spectrometer in $\mathrm{KBr}$ pellets and $\mathrm{NaCl}$ cell. High-performance liquid chromatography was performed on a Waters Associates Model 244 liquid chromatograph (Mildford. MA) equipped with a Model $6000 \mathrm{~A}$ solvent delivery sy stem. Model 440 UV absorbance detector fixed at $25+\mathrm{nm}$, and Model U6K universal injector. Lichrosorb \$I-60 column was used for preparative analyses. Microwave-assisted reactions were conducted in a commercially available microwave reactor. MicroSYNTH. equipped with an infrared temperature detector. The temperatures were controlled within less than $\pm 1-2^{\circ} \mathrm{C}$ in the temperaturecontrolled microwave-assisted reaction. Thin layer chromatography (TLC) was performed on Sigma-Aldrich pre-coated silica gel $\mathrm{F}_{25+}$ aluminum foils. Purification of the reaction products was carried out by flash column cluronatograply using a glass column dry packed with silica gel (230-400 mesh ASTM).

Matelials. Tetrahydrofuran was refluxed over sodium benzophenone and distilled under nitrogen. Methanol (HPLC grade), benzene (HPLC grade), and $n$-hexane (HPLC grade) were distilled from $\mathrm{CaH}_{2}$ before use. $\mathrm{Et}_{\hat{i}} \mathrm{~N}$ was distilled from $\mathrm{CaH}_{2}$ and stored over $\mathrm{KOH}$ pellets. Solvents of reagent grade for cluronatography were used without further purification. Spectroscopic grade solvents were used for HPLC and UV absorption spectra.

Synthesis of (2-hydroxyphenyl)pentamethyldisilane 1. Triethy lamine $(0.76 \mathrm{~mL} .5 .45 \mathrm{mmol})$ was added to a solution of 2-iodophenol ( $1 \mathrm{~g}, 4.54 \mathrm{mmol})$ in tetrahydrofuran $(30 \mathrm{~mL})$ at room temperature under nitrogen atmosphere. Chloropentamethyldisilane ( $1.05 \mathrm{~mL}, 5.45 \mathrm{mmol}$ ) was added dropwisely to the resulting solution and the mixture was refluxed for $3 \mathrm{~h}$. The reaction mixture was filtered with celite, and concentrated in vacuo. To this reaction residue. THF $(30 \mathrm{~mL})$ was added. This resulting reaction solution was added to $\mathrm{Mg}(0.33 \mathrm{~g} .13 .6$ nmol) at room temperature under nitrogen atmosphere and the mixture was refluxed for $1 \mathrm{~h}$. The reaction mixture was 
filtered with celite, and concentrated in vacuo. Water $(30 \mathrm{~mL})$ was added to the solution and extracted with ethyl acetate $(3 \times$ $15 \mathrm{~mL}$ ). The combined ethyl acetate solution was washed with water $(20 \mathrm{~mL})$, brine $(20 \mathrm{~mL})$ and dried $\left(\mathrm{MgSO}_{4}\right)$. The solvent was evaporated in vacuo to give the cnide product. Flash column chromatography with $n$-hexane/ethyl acetate $(10 / 1$. $\mathrm{v} / \mathrm{v})$ as an eluent gave $1(0.81 \mathrm{~g} .80 \%$ yield) as a colorless oil: ${ }^{1} \mathrm{H} \mathrm{NMR}\left(\mathrm{CDCl}_{3} .300 \mathrm{MHz}\right) \delta_{\mathrm{H}} 0.11(9 \mathrm{H}, \mathrm{s}), 0.39(6 \mathrm{H} . \mathrm{s}), 4.86$ $(1 \mathrm{H}, 5), 6.68(1 \mathrm{H}, \mathrm{dd}, J=8.1 .0 .9 \mathrm{~Hz}) .6 .96(1 \mathrm{H} . \mathrm{td}, J=7.4 .0 .9$ Hz). $7.24(\mathrm{lH}$. ddd $J=9.7 .4 .1 .8 \mathrm{~Hz}) .7 .37(\mathrm{lH}$. dd. $J=7.4$. $1.8 \mathrm{~Hz}) ;{ }^{13} \mathrm{C}$ NMR $\left(\mathrm{CDCl}_{3 .} 75 \mathrm{MHz}\right) \delta_{\mathrm{C}} \cdot 3.49,-1.66,114.3$. 120.8. 125.1. 130.4. 135.6. 160.2: UV $\left(\mathrm{CH}_{2} \mathrm{Cl}_{2}\right) \lambda_{\text {max }} 286.279$ IUm; FT-IR (NaCl) 3536.9, 3066.7, 2950.8, 2893.9. 1592.9. $1437.1,1275.7,1243.9 .835 .1 .799 .2 \mathrm{~cm}^{.1}:$ MS $(70 \mathrm{eV}) \mathrm{mzz}$ $224\left(\mathrm{M}^{-}\right): \mathrm{MS} m / z(\%) 224\left(\mathrm{M}^{+} .2 .5\right) .209$ (100). $193(70) .151$ (19). 133 (33.5). 91(12): HRMS $\left(\mathrm{M}^{+}\right)$calcd for $\mathrm{C}_{11} \mathrm{H}_{20} \mathrm{OSi}_{2}$ $22+.1053$, found 224.1075

Synthesis of (2-hydroxyethoxyphenyl)pentamethyldisilane 2. To a solution of (2-hydroxyphenyl)pentamethyldisilane $\mathbf{1}$ $(0.5 \mathrm{~g}, 2.23 \mathrm{mmol})$, sodium hydroxide $(0.45 \mathrm{~g} .11 .2 \mathrm{mmol})$. and tetrabutylammonium iodide $(0.082 \mathrm{~g}, 0.223 \mathrm{mmol})$ in water $(5 \mathrm{~mL})$ was added dropwisely 2 -chloroethanol $(0.45$ $\mathrm{mL}, 6.69 \mathrm{mmol}$ ) at room temperature. The reaction mixture was irradiated in MicroSYNTH operated at $500 \mathrm{~W}$ for $\mathrm{l}$ hr at $40{ }^{\circ} \mathrm{C}$ temperature. Water $(5 \mathrm{~mL}$ ) was added to the solution and extracted with ethyl acetate $(3 \times 10 \mathrm{~mL})$. The combined ethyl acetate solution was washed with water $(10 \mathrm{~mL})$. brine $(10 \mathrm{~mL})$ and dried $\left(\mathrm{MgSO}_{4}\right)$. The solvent was evaporated in vacuo to give the crude product. Flash column chromatography with $n$-hexane/ethyl acetate $(5 / 1 ., / v)$ as an eluent gave 2 $(0.57 \mathrm{~g} .95 \%$ yield $)$ as a colorless oil: ${ }^{1} \mathrm{H} \mathrm{NMR}\left(\mathrm{CDCl}_{3} .300\right.$ $\mathrm{MHz}) \hat{o}_{\mathrm{H}} 0.07(9 \mathrm{H}, \mathrm{s}) .0 .37(6 \mathrm{H} . \mathrm{s}), 1.96(1 \mathrm{H}, \mathrm{s}) .3 .99(2 \mathrm{H}, \mathrm{m})$. $4.11(2 \mathrm{H} . \mathrm{m}) .6 .83(1 \mathrm{H}, \mathrm{d}, J=8.4 \mathrm{~Hz}), 6.98(1 \mathrm{H} . \mathrm{t} . J=7.5 \mathrm{~Hz})$. $7.3+(2 \mathrm{H}, \mathrm{m}){ }^{13} \mathrm{C} \mathrm{NMR}\left(\mathrm{CDCl}_{3}, 75 \mathrm{MHz}\right)$ o $-2.99 .-1.60 .61 .7$. 69.0. 110.1. 121.1. 127.4, 130.5, 135.6. 163.1; UV $\left(\mathrm{CH}_{2} \mathrm{Cl}_{2}\right)$ $\partial_{\text {max }} 286.279 \mathrm{~nm}$ : FT-IR $(\mathrm{NaCl}) 3359.3 .3062 .9 .2949 .3$. $2892.7,1585.1,1436.5,1232.0,793.7 \mathrm{~cm}^{-1}$; MS $(70 \mathrm{eV}) \mathrm{mz}$ $268\left(\mathrm{M}^{-}\right)$: MS $m / z(\%) 268\left(\mathrm{M}^{+} .0 .1\right) .252$ (14). 223 (18) 209 (30). 179 (100). 133 (44). 123 (29). 73 (14): HRMS (M) calcd for $\mathrm{C}_{13} \mathrm{H}_{24} \mathrm{O}_{2} \mathrm{Si}_{2} 268.1315$, found 268.1370 .

Synthesis of (2-allyloxyethoxyphenyl)pentamethyldisilane 3. To a solution of (2-hydroxyethoxypheny l)pentamethy ldisilane 2 (0.5 g. $1.86 \mathrm{mmol})$. sodium hydroxide $(0.37 \mathrm{~g} .9 .32$ mmol), and tetrabutylammonium iodide $(0.068 \mathrm{~g}, 0.186 \mathrm{mmol})$ in water $(5 \mathrm{~mL})$ was added dropwisely allyl bromide $(0.48$ $\mathrm{mL} .5 .59 \mathrm{mmol}$ ) at room temperature. The reaction mixture was irradiated in MicroSYNTH operated at $500 \mathrm{~W}$ for $45 \mathrm{~min}$ at $66^{\circ} \mathrm{C}$ temperature. Water $(5 \mathrm{~mL})$ was added to the solution and extracted with ethyl acetate $(3 \times 10 \mathrm{~mL})$. The combined ethyl acetate solution was washed with water $(10 \mathrm{~mL})$. brine $(10 \mathrm{~mL})$ and dried $\left(\mathrm{MgSO}_{4}\right)$. The solvent was evaporated in vacuo to give the crude product. Flash column chromatography with n-hexane/ethyl acetate $(15 / \mathrm{l}, \mathrm{v} / \mathrm{v})$ as an eluent gave 3 (0.54 g. 94\% y ield) as a colorless oil: ${ }^{1} \mathrm{H}$ NMR (CDCl. 300 $\mathrm{MHz}) \hat{\delta}_{\mathrm{H}} 0.09(9 \mathrm{H}, \mathrm{s}) .0 .39(6 \mathrm{H}, \mathrm{s}), 3.85(2 \mathrm{H}, \mathrm{t} . J=3.9 \mathrm{~Hz})$. $4.09(2 \mathrm{H}$. d. $J=4.2 \mathrm{~Hz}) .4 .17(2 \mathrm{H}, \mathrm{t} . J=3.9 \mathrm{~Hz}), 5.24(1 \mathrm{H} . \mathrm{d}$, $J=7.8 \mathrm{~Hz}), 5.35(1 \mathrm{H} . \mathrm{dd} . J=12.9,1.2 \mathrm{~Hz}), 5.98(1 \mathrm{H} . \mathrm{m}) .6 .84$ (IH. d. $J=6 \mathrm{~Hz}), 6.98(\mathrm{IH} . \mathrm{t} . J=5.4 \mathrm{~Hz}) .7 .34$ (IH. td. $J=6$.
$0.9 \mathrm{~Hz}) .7 .38(1 \mathrm{H}$. dd. $J=5.4 .0 .9 \mathrm{~Hz}):{ }^{12} \mathrm{C} \mathrm{NMR}\left(\mathrm{CDCl}_{5} .75\right.$ $\mathrm{MHz}) \delta_{\mathrm{C}}-3.50,-1.81,66.4,68.5,72.1,109.5,117.2,120.5$. $127.2,130.1,134.5,135.1,162.9$ : UV $\left(\mathrm{CH}_{2} \mathrm{Cl}_{2}\right) t_{\text {max }} 286,280$ nn; FT-IR (NaCl) 3063.4, 2949.3, 2892.8, 1585.4, 1436.4, 1231.8. $1128.7,926.6 \mathrm{~cm}^{-1}$ : MS $(70 \mathrm{eV}) \mathrm{m} / \mathrm{z} 308\left(\mathrm{M}^{+}\right)$: MS $\mathrm{m} / \mathrm{z}(\%) 308\left(\mathrm{M}^{-}, 2\right) .267(7), 235(30), 192(100) .164(52)$. $150(17) .118(8) .74(55)$ : $\mathrm{HRMS}\left(\mathrm{M}^{+}\right)$calcd for $\mathrm{C}_{16 \mathrm{H}_{28} \mathrm{O}_{2} \mathrm{Si}_{2}}$ 308.1628 . found 308.1637 .

Synthesis of (2-acetoxyethoxyphenyl) pentamethỵldisilane 4. A solution of (2-hydroxyethoxy phenyl)pentamethyldisilane $2(0.5 \mathrm{~g} .1 .86 \mathrm{mmol})$ in $N, V$-dimethy lformanide $(5 \mathrm{~mL})$ was added to a solution of $\mathrm{NaH}(0.05 \mathrm{~g} .2 .23 \mathrm{mmol})$ in DMF (5 $\mathrm{nL})$ at roon temperature under nitrogen atmosphere. Acetyl chloride $(0.27 \mathrm{~mL} .3 .73 \mathrm{mmol})$ was added dropwise to the resulting solution and the reaction mixture was irradiated in MicroSYNTH operated at $500 \mathrm{~W}$ for 1 hr at $80^{\circ} \mathrm{C}$ temperature. Water (10 $\mathrm{mL})$ was added to the solution and extracted with ethyl acetate $(3 \times 10 \mathrm{~mL})$. The combined ethyl acetate solution was washed with water $(10 \mathrm{~mL})$. brine $(10 \mathrm{~mL})$ and dried $\left(\mathrm{MgSO}_{4}\right)$. The solvent was evaporated in vacuo to give the crude product. Flash column chromatography with $n$-hexane/ ethyl acetate $(5: 1$. v/v) as an eluent gave $+(0.32 \mathrm{~g} .55 \%$ yield $)$ as a colorless oil: ${ }^{l} \mathrm{H} N M R\left(\mathrm{CDCl}_{3}, 300 \mathrm{MHz}\right) \delta_{\mathrm{H}} 0.043(9 \mathrm{H}$, s). $0.34(6 \mathrm{H}, \mathrm{s}) .2 .09(3 \mathrm{H}, \mathrm{s}) .4 .18(2 \mathrm{H}, \mathrm{m}) .4 .44(2 \mathrm{H}, \mathrm{m}) \cdot 6.78$ (1H. d. $J=8.1 \mathrm{~Hz}$ ). 6.97 (1H. td. $J=7.5,0.9 \mathrm{~Hz}$ ); ${ }^{13} \mathrm{C}$ NMR $\left(\mathrm{CDCl}_{3}, 75 \mathrm{MHz}\right) \hat{o}_{\mathrm{C}}-3.23,-1.53,21.2,63.1 .65 .5 .109 .7$. $112.1,121.2,130.5,135.6,156.1,168.6: \mathrm{UV}\left(\mathrm{CH}_{2} \mathrm{Cl}_{2}\right) \lambda_{\text {max }}$ $286.279 \mathrm{~nm}$; FT-IR (NaCl) 3063.3, 2950.2, 2893.3. 1745.8, 1585.6. 1437.0. 1220.2. 1067.5.793.7 $\mathrm{cm}^{-1}: \mathrm{MS}(70 \mathrm{eV}) m: z$ $310\left(\mathrm{M}^{-}\right)$: MS $m / z(\%) 310\left(\mathrm{M}^{-}, 0.8\right), 267(2), 237(100), 193$ (30). $179(55) .151(17) .87(76) .75(12)$ : HRMS (M-) calcd for $\mathrm{C}_{1} \mathrm{H}_{26} \mathrm{O}_{3} \mathrm{Si}_{2} 310.1+20$. found 310.1401

Irradiation of (2-hydroxyethoxyphenyl)pentamethyldisilane 2 in methanol. A solution $\left(5 \times 10^{-4} \mathrm{M}\right)$ of (2-hydroxyethoxyphenyl)pentamethyldisilane 2 ( $13+\mathrm{mg}$ ) in methanol ( $1 \mathrm{~L}$ ) was deaerated by nitrogen purging for $\mathrm{l} \mathrm{hr}$ and irradiated in a Rayonet photochemical reactor, model RPR-208. equipped with RUL $254 \mathrm{~nm}$ lamps. After irradiation for $1 \mathrm{hr}$, the resulting photoreaction mixture was concentrated in vacuo. The photoproducts 5 and 6 were isolated in $(53.9 \mathrm{mg} .55 \%$ yield) and (3.5 $\mathrm{mg}$. $5 \%$ yield), respectively, in addition to $2 \%(2.7 \mathrm{mg})$ of the starting material 2 by column chromatography with $n$-hexane/ethyl acetate $(4 / 1, \mathrm{v} / \mathrm{v})$ as an eluent followed by normal phase HPLC using $n$-hexane/ethyl acetate $(2 / 1$. v/v) as an eluent. 5: ${ }^{1} \mathrm{H} N M R\left(\mathrm{CDCl}_{3} .300 \mathrm{MHz}\right) \hat{o}_{\mathrm{H}} 0.37(6 \mathrm{H}, \mathrm{d} . J=$ $3 \mathrm{~Hz}), 1.98(1 \mathrm{H}, \mathrm{s}), 3.98(2 \mathrm{H}, \mathrm{m}) .4 .12(2 \mathrm{H}, \mathrm{m}) .4 .46(\mathrm{lH}$ septet. $J=3 \mathrm{~Hz}) .6 .84(1 \mathrm{H}, \mathrm{d}, J=6 \mathrm{~Hz}) .6 .99(1 \mathrm{H}, \mathrm{t}, J=5.4 \mathrm{~Hz}), 7.37$ (lH. td $J=6.1 .2 \mathrm{~Hz}), 7.45(\mathrm{lH}$, dd $J=5.4 .1 .2 \mathrm{~Hz}){ }^{13} \mathrm{C} \mathrm{NMR}$ $\left(\mathrm{CDCl}_{3}, 75 \mathrm{MHz}\right) \hat{\mathrm{o}}_{\mathrm{c}}-3.46,61.8,69.3 .110 .6,121.3,125.7$, $131.5,136.0,163.3:$ UV $\left(\mathrm{CH}_{2} \mathrm{Cl}_{2}\right) \lambda_{\text {Tll }}$ 284, $278 \mathrm{~nm}:$ FT-IR $(\mathrm{NaCl}) 3376.5,3063.5,2955.7,2876.5,2117.6 .1587 .4$. $1437.3,1235.8,1082.3 .783 .7 \mathrm{~cm}^{-1}$; MS $(70 \mathrm{eV}) \mathrm{mz} 196\left(\mathrm{M}^{+}\right)$. MS $m / z(\%) 196\left(\mathrm{M}^{-}, 12\right) .179(81), 162(100) .136(14) .134$ (5). 102 (38). 92 (26). $76(4) .54$ (3); HRMS (M+) calcd for $\mathrm{C}_{1} \mathrm{H}_{16} \mathrm{O}_{2} \mathrm{Si} 196.0920$. found 196.0936. 6: ${ }^{\mathrm{l}} \mathrm{H} \mathrm{NMR}\left(\mathrm{CDCl}_{3}\right.$. $300 \mathrm{MHz}) \delta_{\mathrm{H}} 2.52$ (1H. s). $3.96(2 \mathrm{H}, \mathrm{nt}), 4.08(2 \mathrm{H} . \mathrm{m}), 6.94$ (3H. m). $7.30(2 \mathrm{H}, \mathrm{m}) ;{ }^{12} \mathrm{C} \mathrm{NMR}\left(\mathrm{CDCl}_{5,75} \mathrm{MHz}\right) \delta_{c} 61.7$. 69.3, 114.8. 121.4. 129.8, 158.8: UV $\left(\mathrm{CH}_{2} \mathrm{Cl}_{2}\right) \lambda_{\max } 278.271$ 
num; FT-IR (NaCl) 3377.4, 2935.7, 1598.9. 1496.5. 1245.5. $1082.1 .916 .1 .754 .5 \mathrm{~cm}^{-1}: \mathrm{MS}(70 \mathrm{eV}) \mathrm{m} / \mathrm{z} 138\left(\mathrm{M}^{+}\right): \mathrm{MS} m / z$ $(\%) 138\left(\mathrm{M}^{+} . \mathrm{l}\right) .135(26) .119(37) .88(45) .86(40) .76(60)$. 74 (100). 60 (53); HRMS (M ) calcd for $\mathrm{C}_{8} \mathrm{H}_{10} \mathrm{O}_{2} 138.0681$. found 138.0623

Irradiation of (2-hydroxyethoxyphenyl)pentamethyldisilane 2 in benzene. A solution $\left(5 \times 10^{-4} \mathrm{M}\right)$ of (2-hydrosyethoxyphenyl)pentamethyldisilane $2(134 \mathrm{mg}$ ) in benzene ( $1 \mathrm{~L}$ ) was deaerated by nitrogen purging for $1 \mathrm{hr}$ and irradiated in a Rayonet photochemical reactor. model RPR-208. equipped with RUL $254 \mathrm{~nm}$ lamps. After irradiation for 2 hr. the resulting photoreaction mixture was concentrated in vaculo. The photoproduct 9 was isolated in $(34.8 \mathrm{mg}, 26 \%$ yield) in addition to $6 \%$ ( $8 \mathrm{mg}$ ) of the starting material 2 by column chromatography with $n$-hexane/ethyl acetate $(4 / 1, v / v)$ as an eluent followed by nomal phase HPLC using n-hexane/ethyl acetate $(2 / 1, v / \mathrm{v})$ as an eluent. 9: UV $\left(\mathrm{CH}_{2} \mathrm{Cl}_{2}\right) \lambda_{\max } 273 \mathrm{~nm}$ : FT-IR (NaCl) 3050.8, 2954.3, 2864.1, 1587.6. 1438.7. 1249.3, $1118.9 .928 .6 .848 .7 \mathrm{~cm}^{-1}: \mathrm{MS}(70 \mathrm{eV}) \mathrm{m} / z 268\left(\mathrm{M}^{+}\right): \mathrm{MS} m / z$ (\%) $268\left(\mathrm{M}^{+} .0 .6\right), 225(7) .195(25), 147(100) .135(32), 95$ (17). $73(80) .59(9)$; HRMS (M) calcd for $\mathrm{C}_{13} \mathrm{H}_{24} \mathrm{O}_{2} \mathrm{Si}_{2}$ 268.1315 , found $268.13+6$

Iradiation of (2-allyloxyethoxyphenyl)pentamethyldisilane 3 in methanol. A solution $\left(5 \times 10^{-4} \mathrm{M}\right)$ of $(2$-allyloxyethoxy phenyl)pentamethỵldisilane 3 ( $154 \mathrm{mg}$ ) in methanol ( $1 \mathrm{~L}$ ) was deaerated by nitrogen purging for $\mathrm{l} \mathrm{hr}$ and irradiated in a Raýonet photochemical reactor. model RPR-208. equipped with RUL 254 num lamps. After irradiation for 30 min. the resulting photoreaction mixture was concentrated in vacuo. The photoproducts 10 and 11 were isolated in $(53.1 \mathrm{mg}, 45 \%$ yield) and (2.7 mg. $3 \%$ yield). respectively. in addition to $4 \%$ (6.2 $\mathrm{mg}$ ) of the starting material 3 by column chromatography with $n$-hexane/ethyl acetate $(5 / 1 . \mathrm{v} / \mathrm{v})$ as an eluent followed by normal phase HPLC using $n$-hexane/ethyl acetate $(2 / 1, v / v)$ as an eluent. 10: ${ }^{\mathrm{H}} \mathrm{H} \mathrm{NMR}\left(\mathrm{CDCl}_{3} .300 \mathrm{MHz}\right) \hat{\mathrm{o}}_{\mathrm{H}} 0.36(6 \mathrm{H}, \mathrm{d}, J=$ $3.9 \mathrm{~Hz}) .3 .83(2 \mathrm{H}, \mathrm{t} . J=4.8 \mathrm{~Hz})+.10(2 \mathrm{H} . \mathrm{dt} . J=5.7 .1 .5 \mathrm{~Hz})$ $4.14(2 \mathrm{H}, \mathrm{t} . J=4.8 \mathrm{~Hz}) .4 .42(1 \mathrm{H}$. septet, $J=3.9 \mathrm{~Hz}) .5 .21(1 \mathrm{H}$. dq. $J=10.1 .2 \mathrm{~Hz}) .5 .32(1 \mathrm{H} . \mathrm{dq} . J=17.1 .5 \mathrm{~Hz}) .5 .95(\mathrm{lH}, \mathrm{m})$, $6.83(\mathrm{lH}, \mathrm{d} . J=8.1 \mathrm{~Hz}), 6.96(1 \mathrm{H}, \mathrm{td} J=7.2 .0 .9 \mathrm{~Hz}) .7 .35(\mathrm{lH}$. ddd. $J=9.3 .7 .5 .1 .8 \mathrm{~Hz}) .7 .45(1 \mathrm{H}$, dd. $J=7.2 .1 .8 \mathrm{~Hz}):{ }^{13} \mathrm{C}$ $\mathrm{NMR}\left(\mathrm{CDCl}_{3}, 75 \mathrm{MHz}\right) \hat{\alpha}_{-}-3.75 .67 .0 .68 .6,72.3,110.1 .117 .1$. 120.6, 125.6. 131.1. 134.6, 135.9, 163.4; UV $\left(\mathrm{CH}_{2} \mathrm{Cl}_{2}\right) \lambda_{\text {max }}$ 285. $278 \mathrm{~nm}$ : FT-IR (NaCl) 3065.0. 2956.2. 2870.7. 2115.7. 1587.5. 1437.4. 1238.6, $1130.9 .889 .4 \mathrm{~cm}^{-1} ; \mathrm{MS}(70 \mathrm{eV}) \mathrm{m} / \mathrm{z}$ $236\left(\mathrm{M}^{-}\right)$: $\mathrm{MS} m / z(\%) 236\left(\mathrm{M}^{-}, 2.5\right), 235$ (15). 191 (31), 179 (84). $151(100), 135(68), 115(38), 91(54) .77(24), 59(9)$ :
HRMS $\left(\mathrm{M}^{+}\right)$calcd for $\mathrm{C}_{13} \mathrm{H}_{2} \mathrm{O}_{2} \mathrm{Si} 236.1233$. found 236.1258 . 11: ${ }^{l} \mathrm{H}$ NMR $\left(\mathrm{CDCl}_{3}, 300 \mathrm{MHz}\right) \hat{\delta}_{\mathrm{H}} 3.82(2 \mathrm{H}, \mathrm{m}) .4 .13(4 \mathrm{H}$, m) $5.23(\mathrm{lH}, \mathrm{dq} . J=10.1 .2 \mathrm{~Hz}) .5 .34(1 \mathrm{H} . \mathrm{dq} . J=17.1 .5 \mathrm{~Hz})$. $5.96(1 \mathrm{H}, \mathrm{m}) .6 .96(3 \mathrm{H} . \mathrm{m}), 7.30(2 \mathrm{H}, \mathrm{m}) ;{ }^{12} \mathrm{C} \mathrm{NMR}\left(\mathrm{CDCl}_{3}\right.$, $75 \mathrm{MHz}) \overrightarrow{\mathrm{o}}_{\mathrm{C}} 67.3,68.6,72.4,114.6,117.4 .120 .9 .129 .5,134.6$. 158.8: UV $\left(\mathrm{CH}_{2} \mathrm{Cl}_{2}\right) \lambda_{\text {max }} 278,272 \mathrm{~nm}$; FT-IR (NaCl) 3064.5 , $2926.9 .2870 .2,1598.6,1495.9 .1244 .9,1113.0,915.3 \mathrm{~cm}^{-1}$ : MS (70 eV) $m z 178\left(\mathrm{M}^{+}\right) ; \mathrm{MS} m / z(\%) 178(\mathrm{M}, 66) .133(17)$. 120 (100). 92 (32). 78 (77). 66 (19); HRMS $\left(\mathrm{M}^{+}\right)$calcd for $\mathrm{C}_{11} \mathrm{H}_{14} \mathrm{O}_{2} 178.0994$. found 178.0921

Irradiation of (2-acetox yethoxyphenyl)pentamethyldisilane 4 in methanol. A solution $\left(5 \times 10^{-4} \mathrm{M}\right)$ of (2-acetoxyethoxy phenyl)pentametlyyl disilane $+(155 \mathrm{mg}$ ) in methanol (1 L) was deaerated by nitrogen purging for $\mathrm{l}$ hr and irradiated in a Rayonet photochemical reactor. model RPR-208. equipped with RUL $25+\mathrm{lm}$ lantps. After irradiation for $2 \mathrm{lur}$, the resulting photoreaction mixture was concentrated in vacuo. The photoproducts 12 were isolated in ( $48 \mathrm{ntg}, 38 \%$ yield) in addition to $9 \%$ ( $14 \mathrm{mg}$ ) of the starting material 4 by column chromatography with $n$-hexane/ethyl acetate $(5 / 1 . \mathrm{v} / \mathrm{v})$ as an eluent followed by normal phase HPLC using $n$-hexane/etlyl acetate (2/1, v/v) as an eluent. 12: ${ }^{1} \mathrm{H} \mathrm{NMR}\left(\mathrm{CDCl}_{2}, 300 \mathrm{MHz}\right) \hat{\delta}_{\mathrm{H}} 0.34$ (9H.s). 2.09 (3H.s), 4.18 (2H. m), $4.44(2 \mathrm{H}, \mathrm{m}), 6.79(1 \mathrm{H}, \mathrm{d}$, $J=8.1 \mathrm{~Hz}) .6 .97(\mathrm{lH} . \mathrm{td} . J=7.5,0.9 \mathrm{~Hz}) .7 .34(2 \mathrm{H}, \mathrm{m}):{ }^{i 3} \mathrm{C}$ $\mathrm{NMR}\left(\mathrm{CDCl}_{3,75 \mathrm{MHz})} \hat{\mathrm{o}}_{\mathrm{C}}-3.47 .21 .2,63.1,65.8 .110 .2,114.9\right.$. $121.3,131.5,136.4 .159 .4 .169 .9$ UV $\left(\mathrm{CH}_{2} \mathrm{Cl}_{2}\right) t_{\max } 285,278$ nim: FT-IR (NaCl) 3055.1, 2983.9, 1735.8, 1587.7, 1438.1, 1265.8. 1046.6, 739.4 $\mathrm{cm}^{-1}$; MS (70 eV) $m / z 252\left(\mathrm{M}^{-}\right)$: MS $m / z(\%) 252\left(\mathrm{M}^{+}, 6\right) .224(63) .211(22) .149(100) .117(11)$. 98 (6). 74 (90). 60 (25): HRMS (M) calcd for $\mathrm{C}_{13} \mathrm{H}_{21} \mathrm{O} 33 \mathrm{Si}$ 252.1182. found 252.1102 .

\section{Results and Discussion}

(2-Hydroxyphenyl)pentamethyldisilane 1 was prepared by the 1.3-migration of pentamethyldisilanyl group in 2-(pentamethyldisilany loxy) phenylmagnesium iodide in tetrahydrofuran. The starting (2-hydroxyethoxy phenyl)pentamethỵldisilane 2 was prepared by the reaction of 2 -chloroethanol with (2-hydrosyphenyl)pentantethyldisilane 1 under nicrowave irradiation using MicroSYNTH in water. The starting (2-allyloxyethosyphenyl)pentamethyldisilane 3 or (2-acetoxyethoxyphenyl)pentamethyldisilane 4 were also prepared by the reaction of allyl bronide or acetyl chloride with (2-hydroxyethosyphenyl)pentametlyyldisilane 2 under microwave irradiation using MicroSYNTH (Scheme 1).

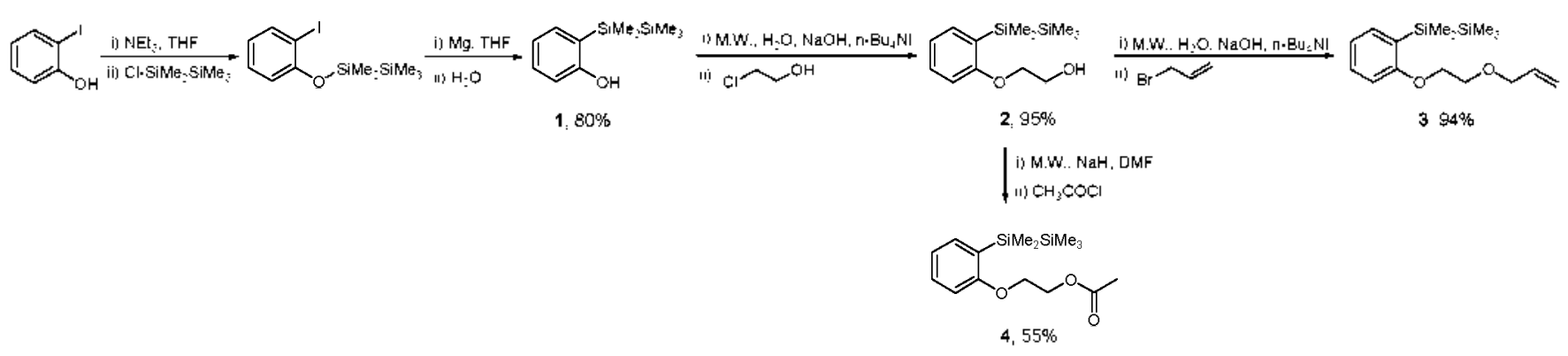




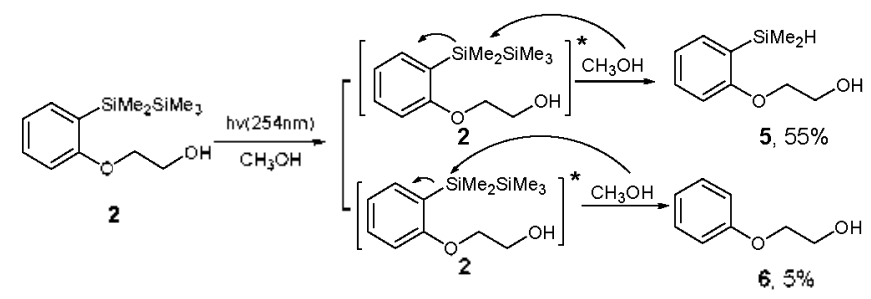

Scheme 2<smiles>C[As](C)(C)c1ccccc1OCCO</smiles><smiles>CCCCCCCCCCCC</smiles>

2

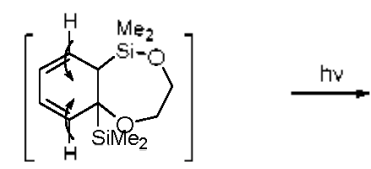

7

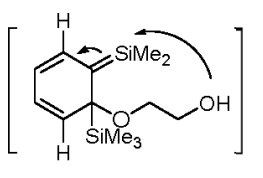

8

Scheme 3

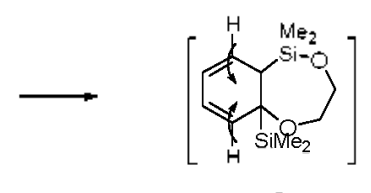

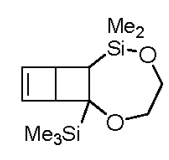

9. $26 \%$
Photoreactions of (2-hydroxyethoxyphenyl)pentamethyldisilane 2. To investigate whether or not the hydroxyethoxy group as ortho substituent in 2 reacts intramolecularly with silatriene moiety formed in the photoexcited state of 2 . the photolysis of 2 was performed.

Irradiation of 2 in deaerated methanol with $254 \mathrm{~nm} \mathrm{UV}$ light afforded 5 ( $55 \%$ yield) and 6 (5\% yield) along with some decomposition products of unknown stnıcture as shown in Scheme 2, when $98 \%$ of 2 was photolyzed but the expected intramolecular photoproduct was not obtained. Indeed, it is well known that the photolysis of substituted phenylpentamethyldisilanes has four reaction pathways: ${ }^{.5}$ (path a) formation of a silene compound and a trimethylsilane ${ }^{2}$. (path b) formation of a silatriene compound arising from 1.3-shift of trimethylsilyl radical. which is formed via homoly tic cleavage of silicon-silicon bond to the $\mathrm{C}_{6}$ position of benzene ring ${ }^{3-15}$ (path c) formation of a trimethylsilyl compound via elimination of a silỵlene. ${ }^{3.18}$ (path d) formation of a direct solvolysis compound accompanied by the formation of trimethylalkoxysilane and

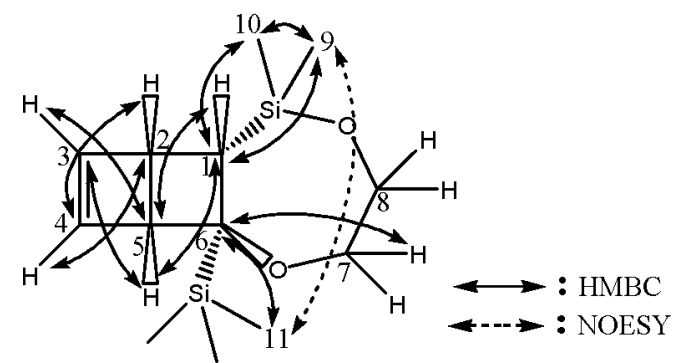

Figure 1. Important correlations observed in HMBC and NOESY spectra of the photoproduct 9 .

trimethylsilane. ${ }^{19,26}$ The formation of a photoproduct 5 or 6 can best be explained in terms of the nucleophilic attack at $\beta$ or $\alpha$ silicon atom of pentamethyldisilanyl group in the photoexcited state of 2 by methanol (path d). The structure of the photoproduct 5 was determined by the ${ }^{1} \mathrm{H} N \mathrm{NR}$ and IR absorption spectra of 5 showing a septet resonance at $\delta 4.46$ and a characteristic absorption at $2117.6 \mathrm{~cm}^{-1}$, respectively. due to a $\mathrm{Si}-\mathrm{H}$ proton and a $\mathrm{Si}-\mathrm{H}$ stretching mode in the diniethylsilyl group of 5 .

Irradiation of 2 in deaerated benzene with $25+$ nm UV light afforded a novel intramolecular photoproduct 9 ( $26 \%$ yield) along with some decomposition products of unknown structure as shown in Scheme 3, when $94 \%$ of 2 was photolyzed. The formation of a novel photoproduct 9 can best be explained in terms of the initial formation of silatriene intermediate 7 arising from 1.3-migration of trimethylsilyl radical. which is formed via the homolytic cleavage of silicon-silicon bond of pentamethyldisilanyl group in the photoexcited state of $\mathbf{2}$ to the $C_{6}$ position of benzene ring (path $b$ ). The intramolecular reaction to form a seven-membered ring in this silatriene intermediate 7 resulted in the formation of the reaction intermediate 8 and then the photochemical disrotatory ring closing of 1,3-butadiene moiety in 8 to cyclobutene gave the novel compound 9. Relatively little is known about the synthesis of the highly strained bicyclo[2.2.0]hex-2-ene moiety in 9 from the photolysis of benzene but the two valence isomers. benzvalene ${ }^{2 ?}$ and Dewar benzene, ${ }^{28-310}$ are reported in benzene photochemistry. In relation to the bicyclo[2.2.0]hex-2-ene moiety in 9 similar to Dewar benzene structure. McDonald

Table 1. ${ }^{1} \mathrm{H} N M R(500 \mathrm{MHz}),{ }^{13} \mathrm{C}$ NMR $(125 \mathrm{MHz})$, and $\mathrm{HMBC}$ data for the photoproduct 9 in $\mathrm{CDCl}_{3}{ }^{\prime \prime}$

\begin{tabular}{|c|c|c|c|c|c|c|c|}
\hline Position & $\partial_{C}(\mathrm{ppm})$ & $\mathrm{M}^{5}$ & $\partial_{H}(p p m)$ & $I^{r^{\prime}}$ & $\mathrm{M}^{\gamma}$ & $J_{\mathrm{H} \cdot \mathrm{H}}(\mathrm{Hz})$ & $\mathrm{HMBC}^{\circ}$ \\
\hline 1 & 28.8 & d & 1.58 & $1 \mathrm{H}$ & d & $7.2\left(J_{(\mathrm{H} \cdot 2 \mathrm{H})}\right)$ & $\mathrm{H} 3, \mathrm{H} 5, \mathrm{H} 9, \mathrm{H} 1 \mathrm{O}$ \\
\hline 2 & 36.6 & d & 2.10 & $1 \mathrm{H}$ & dt & $7.2\left(J_{2 \mathrm{H} \cdot \mathrm{lH}}\right), 2.7\left(J_{2 \mathrm{H} \cdot 3 \mathrm{H}, \mathrm{HH}}\right)$ & $\mathrm{H} 3, \mathrm{H} 4, \mathrm{H} 5$ \\
\hline 3 & 133.9 & d & 5.38 & $1 \mathrm{H}$ & $\mathrm{dq}$ & $5.5\left(J_{3 \mathrm{H} \cdot \mathrm{H} H}\right), 1.2\left(J_{3 \mathrm{H} \cdot \mathrm{lH}, \mathrm{H}, 3 \mathrm{H}}\right)$ & $\mathrm{Hl}, \mathrm{H} 4, \mathrm{H} 5$ \\
\hline 4 & 126.5 & d & 5.59 & $1 \mathrm{H}$ & $\mathrm{dt}$ & $5.5\left(J_{4 \mathrm{H} \cdot 3 \mathrm{H}}\right) .2 .4\left(J_{4 \mathrm{H} \cdot 2 \mathrm{H}, 5 \mathrm{H}}\right)$ & $\mathrm{H} 2, \mathrm{H} 3$ \\
\hline 5 & 38.4 & d & 1.98 & $1 \mathrm{H}$ & $\mathrm{m}$ & & $\mathrm{H} 1, \mathrm{H} 3, \mathrm{H} 4$ \\
\hline 6 & 60.6 & $s$ & & & & & $\mathrm{Hl}, \mathrm{H} 5, \mathrm{H} 7, \mathrm{Hll}$ \\
\hline 7 & 69.5 & $\mathrm{t}$ & 3.67 & $2 \mathrm{H}$ & $\mathrm{m}$ & & $\mathrm{H} 8$ \\
\hline 8 & 65.1 & $\mathrm{t}$ & 3.93 & $2 \mathrm{H}$ & $\mathrm{m}$ & & $\mathrm{H} 7$ \\
\hline 9 & -0.2 & $q$ & 0.15 & $3 \mathrm{H}$ & $s$ & & $\mathrm{HlO}$ \\
\hline 10 & 0.07 & $q$ & 0.18 & $3 \mathrm{H}$ & $s$ & & $\mathrm{Hs}$ \\
\hline 11 & -3.44 & q & 0.004 & $3 \mathrm{H}$ & s & & \\
\hline
\end{tabular}

"All these assigmments were confirmed by ${ }^{1} \mathrm{H}-{ }^{1} \mathrm{H}$ and ${ }^{1} \mathrm{H}^{13} \mathrm{C}$ COSY and NOESY. HMBC spectra. "Multiplicities were detenmined by DEPT spectrum. "Integrated intensity: "Multiplicities. "Protons correlated to carbon resonances in ${ }^{13} \mathrm{C}$ column. 
and Reineke $e^{31}$ found that the photoreaction of cis-1.2-dilydrophthalic anhydride gave bicyclo[2.2.0]hex-5-ene-2.3-dicarboxylic anhy'dride and the intramolecular electrocyclic $[4 \pi]$-ring closure of 2-pyridone to 3-0xo-2-azabicyclo $[2,2,0]$ 5 -hexene ${ }^{3-36}$ was reported. The structure of the photoproduct 9 was determined by various physical methods, such as ${ }^{l} \mathrm{H}$ NMR. ${ }^{13} \mathrm{C}$ NMR, 2D NMR $\left({ }^{1} \mathrm{H}-{ }^{j} \mathrm{H}\right.$ COSY. ${ }^{1} \mathrm{H}-{ }^{13} \mathrm{C}$ HETCO. HMBC. and NOESY). UV. FT-IR. and high resolution mass spectrometry. The ${ }^{1} \mathrm{H}$ NMR spectrum of 9 shows one double bond (at 5.38 and $5.59 \mathrm{ppm}$ ) and three aliphatic protons (at 1.58. 1.98 , and $2.10 \mathrm{ppm})$ and cis coupling constant $(J=$ $7.2 \mathrm{~Hz}$ ) between proton $I$ and proton 2 in the cyclobutane ring in 9. From the correlated peaks in the ${ }^{1} \mathrm{H} \cdot{ }^{13} \mathrm{C}$ HETCO spectrum of 9 . we have been able to identify the pairs of protons directly' attached to the individual carbons as shown in Table 1. To obtain the informations about the structure skeleton of 9 , the HMBC spectrum of 9 was obtained. The connectivity of the carbon C (1) to the dimethylsilyl group in 9 was established by the presence of the cross-peaks due to the vicinal coupling between the protons of $C(9)$ and $C(10)$ and the carbon $C(1)$ in 9. In the same manner, the presence of the cross-peaks due to the vicinal coupling between the protons of $\mathrm{C}(7)$ and $\mathrm{C}(11)$ and the quatemary carbon $\mathrm{C}(6)$ in 9 showed the connectivity of the carbon $C(6)$ to the seven-membered ring and trimethylsilyl group in 9 . The two methyl protons of carbon $\mathrm{C}(9)$ and carbon $\mathrm{C}(10)$ located on the same silicon atom adjacent to a stereocenter (carbon 1) in $\mathbf{9}$ are diastereotopic, and they not only have different chemical shifts $(0.15$ and $0.18 \mathrm{ppm}$. respectively' in ${ }^{1} \mathrm{H} \mathrm{NMR}$ ) but they also show the presence of the cross-peaks due to the vicinal coupling between the protons of $C(10)$ and the carbon $C(9)$, the protons of $C$ (9) and the carbon $\mathrm{C}(10)$ in the HMBC spectrum of 9 . From the presence of the cross-peaks between the protons of $\mathrm{C}(9)$. $\mathrm{C}(10)$ and the protons of $\mathrm{C}$ (11) which is showed in a nuclear overhauser and exchange spectroscopy (NOESY) of 9. it was determined that these protons are located on the same side of the molecule. Thus, the skeletal structure of 9 was unambiguously established as shown in Figure 1.

Photoreaction of (2-allyloxyethoxyphenyl)pentamethyldisilane 3. To investigate whether or not the allyloxyethoxy group as ortho substituent in $\mathbf{3}$ reacts intramolecularly with silatriene moiety formed in the photoexcited state of 3 , the photolysis of 3 was performed.

Photolysis of 3 in deaerated methanol with $25+$ num UV light gave 10 ( $45 \%$ yield) and 11 ( $3 \%$ yield) along with some decomposition products of unknown stnicture as shown in Scheme 4 . when $96 \%$ of 3 was photolyzed but the expected intramolecular photoproduct was not obtained. The formation of a photoproduct 10 or 11 can also be explained by the same way as the formation of a photoproduct 5 or 6 (path d). The structure of the photoproduct 10 was also determined by the ${ }^{1} \mathrm{H}$ NMR and $\mathbb{R}$ absorption spectra of $\mathbf{1 0}$ showing a septet resonance at $\hat{o} 4.42$ and a characteristic absorption at 2115.7 $\mathrm{cm}^{-1}$. respectively, due to a Si-H proton and a $\mathrm{Si}-\mathrm{H}$ stretching mode in the dimethy lsilyl group of $\mathbf{1 0}$.

Photoreaction of (2-acetoxyethoxyphenyl)pentamethyldisilane 4. To investigate whether or not the acetoxyethosy group as ortho substituent in $\mathbf{4}$ reacts intramolecularly with

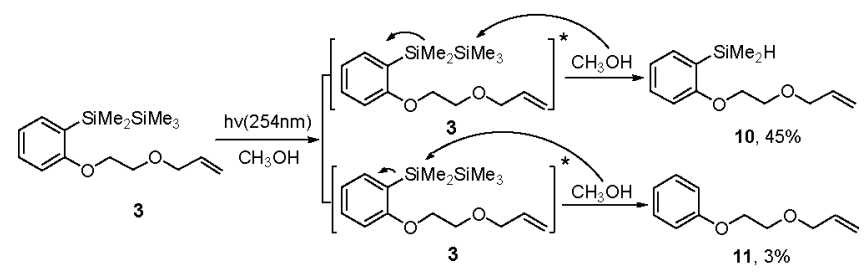

Scheme 4

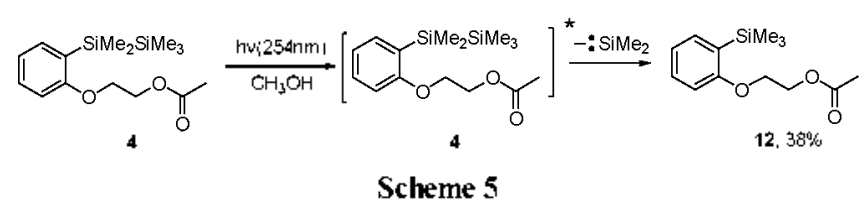

silatriene moiety formed in the photoexcited of $\mathbf{4}$, the photolysis of $\downarrow$ was performed

Photolysis of $\mathbf{4}$ in deaerated methanol with $254 \mathrm{~nm}$ UV light gave 12 ( $38 \%$ yield) along with some decomposition products of unknown structure as shown in Scheme 5 , when $91 \%$ of $\boldsymbol{t}$ was photolyzed but the expected intramolecular photoproduct was not obtained. Liberation of dimethylsilylene species from the photoexcited state of + resulted in the formation of 12 (path c). In contrast to the photoreaction of 3 or 4 in methanol. no product was detected in the photolysis of 3 or 4 in deaerated benzene. indicating that the hydroxyethoxy group is much more reactive than the allyloxyethoxy or acetoxyethoxy group as the ortho-substituted group to phenylpentamethyldisilane in this intramolecular photoreaction.

In conclusion. irradiation of $\mathbf{2}$ in benzene gave the novel intramolecular cyclization photoproduct 9. It is thought that the cyclization photoproduct 9 was probably formed via silatriene intermediate 7. seven-membered ring compound $\mathbf{8}$ having the 1.3-butadiene moiety, and then the photochemical disrotatory ring closure of 1,3-butadiene to cyclobutene. The photoly sis of 2 or 3 in methanol provided 5 and 6 , or 10 and 11 . respectively. which were probably formed through the $\beta$ or $a$ silicon atom attack of methanol to pentamethyldisilanyl group in photoexcited state of $\mathbf{2}$ or 3 . The formation of 12 in the photoreaction of $\mathbf{4}$ in methanol can be rationalized in terms of the elinination of dimethylsilylene species in the excited state of $\mathbf{4}$ but the expected intramolecular photoproducts from the reaction of the silatriene intermediate with ortho substituents were not obtained in the photolysis of 2.3 , and + in methanol solvent.

\section{Refeiences}

1. Ishikawa, M.; Fuchikami, T.; Susaya, T.; Kumada, M. J. Am. Chem. Soc. 1975, 97, 5923

2. Nate, $\mathrm{K} ;$ Ishikawa, $\mathrm{M}$; $\mathrm{Ni}, \mathrm{H}$; Watanabe, $\mathrm{H}$; Saheki, $\mathrm{Y}$. Organometallics $1987,6,1673$.

3. Ishikawa, M. Pwe Appl Chem. 1978, 50, 11,

4. Ishikawa, M.; Fuchikami, T.; Kumada, M. J. Organomet. Chem. $1976,118,139$

5. Ishikawa, M:- Fuchikami, T.; Kumada, M. J. Orgonontet. Chem. $1976,118,155$

6. Ishikawa, M.: Fuchikami, T:; Kumada, M. Tetrahedron Lett. 1976. 1299

7. Ishikawa, M.; Fuchikami, T:; Kumada, M. J. Orgonontet. Chem. 
$1977,133,19$

8. Ishikawa, M.; Fuchikami, T.: Kumada, M. J. Organomet. Chem. 1978, 162, 223.

9. Ishikawa, M.; Oda, M: Mivoshi, N: Fabry, L.; Kumada, M.; Yamabe, T: Akagi, K: Fukui, K. J. An. Chem. Soc. 1979, 101, 4612 .

10. Ishikawa, M. Oda, M.: Nishimura, K.: Kumada, M. Bull Chem. Soc. Jpn. $1983,56,2795$

11. Ohshita, T.: Ohsaki, H.: Ishikawa, M: Tachibana, A.; Kurosaki, Y.; Yamabe, T.: Minato, A. Organometallics 1991, 10,880.

12. Takaki, K.: Sakamoto, H.: Nishinura, Y.; Sugihara, Y: Ishikawa, M. Organometallics 1991, 10,888.

13. Ohshita, T.: Ohsaki, H.: Ishikawa, M.: Tachibana, A.: Kurosaki, Y: Yamabe, T:; Tsukihara, T.; Takahashi, K.; Kiso, Y. Organometallics $1991,10,2685$

14. Ohshita, T,; Ohsaki, H.: Ishikawa, M. Organometallics 1991, 10, 2695.

15. Ishikawa, M.: Nishimura, Y:; Sakamoto, H. Organometallics $1991,10,2701$.

16. Salurai. H.: Nakadaira. Y.: Kira. M.: Sugivama. H.: Yoshida. K.: Takiguchi, T. J. Organonet. Chem. 1980, 184, C36

17. Sakurai, H.: Sakamoto, K.; Kira, M. Chent. Lett. 1984, 1213

18. Kira, M.: Sakanoto, K.; Sakurai, H. J. Am. Chem. Soc. 1983, 105,7469 .

19. Okinoshima, H: Weber, W. P. J. Organonet. Chem 1978, $1+9,279$

20. Hu, S. S.; Weber, W. P. J. Organonet. Chem. 1989, 369, 155.
21. Park, S. K. J. Photochem. Photobiol A. Chem 2005, 173, 29.

22. Park, S. K. Bull. Kolean Chem. Soc. 2006, 27, 1305.

23. Park, S. K. Bull. Korean Chem. Soc. 2008, 29, 1018.

24. Park, S. K: Baek, D. T. J. Photochem. Photobiol . A: Chem. 2004. 163,87 and references cited therein.

25. Kirá, M.; Miyazawa, T.: Sugiyama, H.: Yamaguchi, M.: Sahurai, H. J.Am. Chem. Soc. 1993, 115, 3116.

26. Park, S. K. Bull. Kowan Chem. Soc, 2007, 28, 1045.

27. Lasome, B.; Bearpark, M. J.; Robb, M. A.; Worth, G. A. J. Phys. Chem. \& 2008, 112, 13017 .

28. Bieri, G.: Heilbronner, E.; Kobayashi, T.: Schmelzer, A. Helvetica Chimica tcta 1976, 59, 2657.

29. Haman, P. T.; Kent, T. E.; O'Dwyer, M. F.; Griffith, D. W. T. $J$. Phy. Chent 1981, 85, 2731 .

30. Franck, R. W.; Mandella, W. L.: Falci, K. I. J. Org. Chem. 1975 , 40,327 .

31. McDonald, R. N.; Reineke, C. E. J. Ant. Chent. Soc. 1967, 32 , 1878 .

32. Selms, R. C.: Schleigh, W. R. Tetrahedron Lett. 1972, 3563.

33. Sato, M: Katagiri, N.: Muto, M:: Haneda, T.: Kaneko, C. Tetrohedron Lett. 1986, 27,6091.

34. Toda, F; Tanaka, K. Tetwahedron Lett. 1988, 29, 4299.

35. Wu, L. C.: Cheer, C. J.: Olovsson, G.; Scheffer, J. R.: Trotter, T.; Wang, S. L.; Liao, F. L. Tetrahedron Lett. 1997, $38,3135$.

36. Bach, T.: Bergmann, H.; Harms, K. Oiganic Letters 2001, 3 , 601 